Tarih Kültür ve Sanat Araştırmaları Dergisi

Revue des Recherches en Histoire Culture et Art

$$
\text { مجلة البحوث التاريخية و الثقافية والفنية }
$$

Vol. 6, No. 5, November 2017

Copyright (C) Karabuk University

http://kutaksam.karabuk.edu.tr

\title{
DOI: 10.7596/taksad.v6i5.1276
}

Citation: Afanasyeva, M., Krylov, V., \& Mikhailova, M. (2017). Andrei Bely's Literary Portraits in the Structure of Critical and Memoir Genre. Journal of History Culture and Art Research, 6(5), 13-18. doi:http://dx.doi.org/10.7596/taksad.v6i5.1276

\section{Andrei Bely's Literary Portraits in the Structure of Critical and Memoir Genre}

\author{
Margarita Afanasyeva ${ }^{1}$, Viacheslav Krylov ${ }^{2}$, Maria Mikhailova ${ }^{3}$
}

\begin{abstract}
Despite the research boom of recent times and the increased interest in Andrei Bely's personality and creativity, which is reflected in numerous articles, monographs, dissertations, international scientific conferences about him, criticism and memoir remains the least studied part of the largest Russian symbolist creative legacy. Unfortunately, A. Bely's critical texts are not fully collected, we do not even have a complete idea of the volume of what he wrote. In order to comprehend the innovation of A. Bely's critical prose, it is necessary to update the research tools of the criticism itself. The correlation problem between A. Bely's creative method in the context of literary critical and memoir genres, the issues about the role and the uniqueness of portrait characteristics in different types of the discourse and the transformations of Bely's early poetics in late memoir and biography were not the subject of a special study, which determines the purpose and the tasks of the article. The performed analysis showed that the image of writers in the critical and memoir portraits is somewhat similar. This can be explained by the fact that Bely's memoir texts are the continuation of his early work. However, the publicistic nature of the criticism and the polemical origin in the memoir genre are weakened. The portrait in the structure of a memoir book is combined with the experience of the lived life and complicated by the synthesis of previous literary-critical interpretations and later evaluations.
\end{abstract}

Keyworlds: Criticism, The silver age, A. Bely, Memoirs, Genre of literary portrait.

\footnotetext{
1 Kazan Federal University, Leo Tolstoy Institute of Philology and Intercultural Communication. E-mail: afanasieva.ms1992@yandex.ru

${ }^{2}$ Kazan Federal University, Leo Tolstoy Institute of Philology and Intercultural Communication.

${ }^{3}$ Lomonosov Moscow State University, Faculty of Philology.
} 


\section{Introduction}

In recent decades, the heritage of the Silver Age (Shamina, 2016; Paperno \& Grossman, 1994; Matich, 2007), in particular, the works by Andrei Bely (Fleishman, 1987; Spivak, 2005a and 2005b; Kapinus, 2013), the leading theoretician of symbolism, a poet, a prose writer, a playwright and a critic, is of interest for contemporary literary criticism. Many researchers turned to his multi-faceted creative heritage, but even today critical and memoir creativity is still on the periphery of research interest with rare exceptions. We are not interested in the ratio of artistic and memoir portraits (Adamyan, 2011), but in the similarities and the differences of contemporary writer portraits, created at different stages of A. Bely's creative path and belonging to different genre systems - the literary-critical essays of the 1900s and late memoirs of the late 1920s and early 1930s. The aim of our work is to reveal the features of A. Bely's critical and memoir portraits poetics and to reveal the changes in his author's manner, based on the evolution of his worldview and the views on the literary process and the whole epoch. The performed study clarified the specifics of A. Bely's creative method in the trilogy, the differences in the principles of portrait creation within literary critical and memoir discourses. The materials and the results of the study can be used in the practice of Russian Silver Age literature teaching, and also contribute to the study of other writer works who worked in a critical and memoir genre. New issues arise related to the study of A. Bely's memoirs creative history, as the writer used the texts of previous critical articles during their writing.

\section{Materials and methods}

The materials for this study are the book of A. Belov's articles "Arabesques" (1911) and the second book of memoirs "The Beginning of the Century" (1932). Not so-called "Berlin" edition of memoirs, but the later version of 1932 is taken for comparison. In the second chapter "Authorship" A. Bely places the sketches about the meetings with Bryusov, Merezhkovsky, Gippius and other figures of symbolism. In order to study the genre specifics and the features of the writer's image creation, the methods of cultural, structural, systemic and comparative analysis were used that allow us to trace how the writer's image changes during earlier literary-critical portraits and memoir portraits written twenty years later, and how the poetics of the literary portrait transforms. The theoretical basis of the study is the works that cover the specific character of the memoir genre, as well as the theory of portrait.

\section{Results and discussion}

It is impossible to compare the poetics of memoir and critical literary portraits, not taking into account their genre features. To do this, we need to recall the goals pursued by the author, creating this or that portrait. The literary portrait as a genre of criticism is inseparable from those functions performed by criticism in the literary process. It is aimed not only at a writer's personality comprehension, but presupposes a well-founded, convincing impact on literature and public opinion. But it is also true that the literary-critical portrait approaches to literature to a greater extent than other critical genres: details, author's self, associativity, and a certain share of fiction play an important role in it. The peculiarity of the memoir portrait is retrospectivity, reliance on facts, biographical materials, personal testimonies about the encounters with heroes, as well as an indispensable subjective character depicted both in the selection and in the evaluation of literary facts. As a rule, the appeal to the writer's personality serves as a dominant in the memoir portrait, and in the critical one to his work in a greater extent. But during the Silver Age, these borders were violated, especially in the works by A. Bely. Almost in all portrait essays A. Bely resorts to stylization, reproducing the elements of stylistics and the atmosphere of the works of writers in order to create the impression necessary for him as the author of a critical work. He "exploits" the beloved trails and other expressive means. And all this is necessary for him to justify subjective conclusions, to establish his own theoretical attitudes. 
A. Bely in the foreword to the book "The Beginning of the Century" writes that he is trying to recreate the attitude towards people and events that he had during the period of the 1900s: "I describe people the way they looked to me more than a quarter of a century ago; It would be pointless to create in the style of their final development the beginning of their path; It means to compile facts that did not take place and to be silent about the facts that took place" (1990). However, later he admits himself that he could not do it, creating the image of Blok, since the relationship with him were always quite complicated.

In order to trace what changes and how during the creation of the writer's image in the critical and memoir portrait, we will analyze the portraits of the same writers in the book of articles "Arabesques" and the second book of memoirs "The Beginning of the Century." Within the framework of the article, we will present the results of only a few comparisons and consider the portraits of V. Bryusov, Z. Gippius and D. Merezhkovsky. At the same time, one should also take into account the fact that some of A. Bely's articles were originally published in newspapers and magazines before he combined them into the book "Arabesques". Therefore, a number of portraits in "Arabesques" consists from several parts (portraits "Merezhkovsky", "Bryusov", "Gippius"), which include a portrait-silhouette, a portrait-essay of creativity and a portrait-review. Let's turn to the portraits-silhouettes, since it is this type of literary portrait that is aimed at the understanding a writer's personality depth, not only on the basis of his creativity, but also on the basis of memories, subjective evaluation, which in part brings this literary-critical portrait closer to memoirs.

Thus, the essay "Merezhkovsky" opens with the silhouette in which A. Bely turns to a reader, as if drawing him to the Summer Garden, where Merezhkovsky is walking. Here A. Bely uses the cinematic technique, the example of which is the beginning of the narrative. A close-up appears before a reader - an image of the Summer Garden, and then the objects are getting closer. A silhouette of a small man appears, followed by the description of his clothes, the transition to a face is performed which is described as pale and cold, and then the focus is aimed on the eyes and his look. The final illustrates an opposite picture: first a small man walking in a blizzard is shown, his image is also drawn, but the last shot is his dissolution in space and time.

The color symbolism is important for A. Bely. It allows to show the role of the person portrayed in the historical process. The key to the explanation of the color symbolism is the article "Sacred Colors". The critic drew a portrait in it of someone who will conquer the world according to Bely (2012). He must have a white face with a wax coating showing the sorrow of the righteous; his eyes are blue and bottomless; his lips red purple, and his hair is gold, as the symbolism of these flowers demonstrates the victory over chaos. White color is a symbol of full life, of light; red symbolizes the final stage of the victory over the enemy (the Devil), so "the remains of the dust that perches on a man burn in such a way"; pink is the combination of red and white, but the latter predominates, which illustrates the predominance of human god light; blue is the symbol of God humanity and duality" (ibid.). Thus, the symbolist Bely, repeatedly emphasizing Merezhkovsky's white, waxy face, sees a "righteous man" in him who approaches the solution of the world secrets.

The book "Arabesques" has the image of Z. Gippius, who, on the one hand, is somewhat opposed to Merezhkovsky (which is conditioned by different temperaments and character of the spouses), and on the other hand it complements him. Describing their room and the very image of Gippius, A. Bely resorted to color symbols once again, using the aforementioned colors: "A large room, covered with red wallpapers. The crimson coals of the fireplace smolder quietly: like a golden leopard, dotted with gray spots, crackles quietly in the fireplace. Z. N. Merezhkovskaya is on the couch in white, with red and gold hair, all in the glare of fire ..." (ibid.). So, the critic, drawing two images and the situation in the room, demonstrates that these people can pass the way: to overcome the chaos of the world and to connect with God. 
In his memoirs "The Beginning of the Century" written twenty years later, A. Bely recreates the same picture when he came to Merezhkovsky's house, talked for a long time, joked with Z. Gippius, and at that time Dmitry Sergeyevich was in another room. The fireplace is also burning, Merezhkovsky is wandering in the same Summer Garden, but only this image is not a man's image outside of time and space, but the image of a little man whom his wife saves from unnecessary conversations: "Dmitry Sergeyevich is a greenhouse, a refined little priest; "He has the appearance of a faster", "an official in his soul, and a capricious and a sensual person in spirit; $\mathrm{He}$ is subjectivist in each detail; He shouted about the community, and fell into fainting from calls, rushing into an office, - from the fans, Gippius sold them" (1990). This portrait has an evident irony, bordering with sarcasm. Although A. Bely wrote that he was trying to show exactly that attitude to contemporaries that he had for them at the beginning of the century, but many portraits were written with irony, and there is no apology that was present in the depiction of writers during the writing of critical portraits.

Often the critic uses the same images, but they are transformed, reinforcing the ironic attitude. Thus, the recollections about Merezhkovsky in memoirs begin with the image of a whirlwind (the image of blizzard, in which the contemporary dissolves, appears in the portrait-silhouette). However, now this is not an opportunity to overcome the deadness of life any longer, as A. Bely saw it before. There is nothing left from the former sense, which was invested earlier: Merezhkovskys become just a "whirlwind of words". Therefore, it is difficult now for Bely to imagine "how could Merezhkovsky's chatter seem like a matter", and how Gippius's verses could then be of interest to him (ibid.). First of all, a caricature portrait of Merezhkovsky and Gippius appears before us, based not so much on humor as on a rigid irony.

The heart of a number of literary critical portraits is represented by the images that become the leitmotif, characteristic of A. Bely's ornamental prose, which demonstrates the properties of symbolist criticism as a writer's one. It should be noted that the leitmotif of the symbolists serves as a poetic analog of "eternal return" theory and indicates the repeatability of what was already there, so "inaccurate repetitions are the symbolic allusions to what was already depicted and perceived either as mythology or as an orientation toward musical structures" (Mintz, 1979). Thus, in the portrait "Merezhkovsky" ("Arabesque") the image of the rapier is used for the image of Z. Gippius by which she treats "soul ulcers" (Bely, 2012). This image is also used in the portrait "Gippius", which, according to the symbolist, corresponds to the style of critical article writing for a depicted person. The heroine of the portrait often spiked the writers, whose work she analyzed in her articles.

In his memoirs A. Bely also emphasizes the ability of Gippius to select words subtly and defend her point of view. However, the critic presents this not with the help of a rapier image, but with the help of a portrayed image of a wasp that stings its opponent: "Z. Gippius is definitely a wasp of a man's height, if not the skeleton of the "captivator" (written by Aubrey Beardsley); The swollen red hair covered a very small and curved little face" (Bely, 1990). Thus, in his memoirs A. Bely continues to use those techniques and images that he applied to portrayed personalities in literary critical portraits, but in order to reveal the image in the book "The Beginning of the Century" more fully he relates his contemporaries to the images of animals.

The same technique is used both in the silhouette "Bryusov", and in the memoir portrait "Valery Bryusov". Already in the book "Arabesques" the critic uses the image of a panther, although this animal is not named: "Ceremonially, he showed you a chair with a spring movement. Be he did not sit down. He was holding on to the back of a chair and was ready to listen to you" (Bely, 2012). It is clear from this passage that the portrait is based on the impressions that arise at Bryusov's sight.

In the memoir portrait, the critic calls Bryusov a panther directly, but this image of a fast animal, reflecting the character of the contemporary and his attitude to work, is supplemented by mythological images and 
allusions, which E.I. Adamyan (2011) noted in her work. Not without irony, A. Bely calls a portrayed person "the purgatory of the Augean literary stables, littered with garbage". Thus, in our opinion, the memoirist expresses his opposition to Bryusov's activities, who sought to gather a literary school around him and fill the literary environment with new contemporary works. The symbolist compares his contemporary with the Atlas, on which the entire literary world is held. If in the critical portrait the author treated Bryusov as a person who tried to implement the theurgic principle of form and content unity in life, but failed to do this completely, then this attitude disappears in the memoir portrait and it is replaced by the irony concerning all Bryusov's literary activity.

Of course, the means of the cartooned image of contemporaries is characteristic of A. Bely as a critic (Lavrov, 1989), but in the memoirs this method becomes a decisive and a reinforced one. Structurally, the arrangement of portraits in Bely's memoirs is peculiar: a memory-evaluation of the general attitude toward the writer in his later evolution precedes the memory of the first meeting. Bely seems to be excusatory in front of a modern reader, explaining close relations with Bryusov, Gippius and Merezhkovsky. The logic of these memories is characterized by constant temporal displacements and numerous projections. It is dictated by the author's conviction that "in the conditions of memory experience development, we connect the isolated strokes into a separate high causality by memory fact selection, which has nothing in common with the mechanical one" (Bely, 2016).

\section{Conclusions}

Summing up, it must be said that the method of writer depiction in literary critical and memoir portraits is somewhat similar. A. Bely used both kinds of portraits to show the era "in faces". The location of the articles in the book "Arabesques" does not correspond to the chronology of their writing and publication. It was determined by the critic's desire to "draw a picture of a finished literary epoch" (Bely, 1994). In his silhouettes, A. Bely deploys metaphorical correspondences, cohesion, associations, which allow him to speak primarily about the author's perception of the portrayed personalities, whom he places in the "appropriate" setting: Merezhkovsky is immersed in "purple laughter", in "gentle, snowy smoke". But as it turns out, the author needs this in order to refute the impulse of the first impression concerning Merezhkovsky's "coldness". This attempt of some justification of the hero is not present in the memoirs.

The strengthening of the revelatory, extremely caricature attitude of the symbolist to the events that took place at the beginning of the century is noticeable.

Although A. Bely wanted to show the writers as they were a quarter of a century ago, but he could not get rid of later estimates and time optics. Therefore, modern assessments of their activity, dictated by Bely's attitude to Merezhkovsky during the writing of the second edition of memoirs, and the general ideological intolerance towards the idealism of the silver age, and by Bely's attempts, at least in public, to dissociate himself from the former symbolist environment and fit into the new Soviet realities invade the memories of the first meeting with Merezhkovsky. But in this case, in the late diaries by A. Bely, we meet only the estimates of time and the surrounding writers' environment. Recently published the most valuable volume of the "Literary Succession" (Volume 105), containing the materials for the biography, the foreshortening to the diary and the diaries of the 1930s, can also be studied within the framework of our theme.

\section{Acknowledgement}

The work is performed according to the Russian Government Program of Competitive Growth of Kazan Federal University. 


\section{References}

Adamyan, E. I. (2011). Artistic Portrait and Memoirs in Prose by A. Bely. Dissertation for Candidate of Philology. Moscow.

Bely, A. (1990). The beginning of the century. Moscow: Union Theater of the USSR STD.

Bely, A. (1994). Criticism. Aesthetics. Theory of symbolism: in 2 volumes. V. 1. Moscow: Art.

Bely, A. (2012). Collected Works. Arabesques. The Book of Articles. Green Meadow. The Book of Articles. Moscow.

Bely, A. (2016). Diary of 1932. Literary heritage, 105. 912-988. Moscow: Nauka.

Fleishman, L. (1987). Bely's Memoirs. In John E. Malmstad (ed.), Andrei Bely: Spirit of Symbolism. Ithaca: CornellUniversity Press.

Kapinus, T. L. (2013). A. Bely's Critical Prose of 1902-1905: Aesthetics and Poetics. Dissertation for Candidate of Philology. Kharkiv.

Lavrov, A. V. (1989). Memoir trilogy and memoir genre by Andrei Bely. Bely A: At the turn of two centuries (pp. 375-401). Moscow: Dmitry Sechin.

Matich, O. (2007). Erotic Utopia: The Decadent Imagination in Russia's Fin de Siecle. University of Wisconsin Press.

Mintz, Z. G. (1979). About some "neomythological" texts in the work of Russian symbolists. Scientist notes of Tatar State University, 459. Block collection III, Tartu, 76-120.

Paperno, I. \& Grossman, J. D. (1994). Creating Life. The Aesthetic Utopia of Russian Modernism. Stanford: Calif Stanford University Press.

Shamina, V. (2016). Mystic motifs in silver age poetry and prose. Ghosts - or the (Nearly) Invisible: Spectral Phenomena in Literature and the Media, 9, 161-169

Spivak, M. (2005). East and/or West, Russia and/or Europe in the Later Works of Andrei Bely. 7th International World Congress for Central and East European Studies (ICCEES) "Europe - our common home?" (pp. 400-401). Berlin.

Spivak, M. (2005). The Fate of Andrei Bely's Archive. 7th International World Congress (ICCEES) "Europe our common home?" Berlin. 